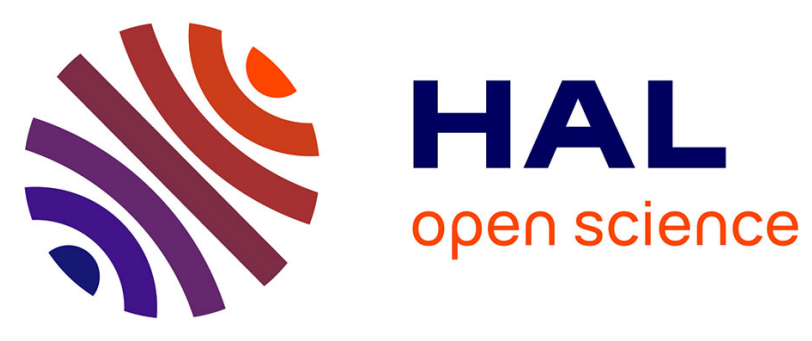

\title{
Influence of drafting during swimming on ratings of perceived exertion during a swim-to-cycle transition in well-trained triathletes
}

\author{
A Delextrat, V Tricot, Christophe Hausswirth, Thierry Bernard, F \\ Vercruyssen, Jeanick Brisswalter
}

\section{To cite this version:}

A Delextrat, V Tricot, Christophe Hausswirth, Thierry Bernard, F Vercruyssen, et al.. Influence of drafting during swimming on ratings of perceived exertion during a swim-to-cycle transition in well-trained triathletes. Perceptual and Motor Skills, 2003, 96 (2), pp.664-666. 10.2466/pms.2003.96.2.664 . hal-01760210

\section{HAL Id: hal-01760210 \\ https: / hal-insep.archives-ouvertes.fr/hal-01760210}

Submitted on 6 Apr 2018

HAL is a multi-disciplinary open access archive for the deposit and dissemination of scientific research documents, whether they are published or not. The documents may come from teaching and research institutions in France or abroad, or from public or private research centers.
L'archive ouverte pluridisciplinaire HAL, est destinée au dépôt et à la diffusion de documents scientifiques de niveau recherche, publiés ou non, émanant des établissements d'enseignement et de recherche français ou étrangers, des laboratoires publics ou privés. 


\title{
Influence of drafting during swimming on ratings of perceived exertion during a swim-to-cycle transition in well-trained triathletes
}

\author{
A. DELEXTRAT ${ }^{1}$, V. TRICOT ${ }^{1}$, C. HAUSSWIRTH ${ }^{2}$, T. BERNARD ${ }^{1}$, F. VERCRUYSSEN ${ }^{1}$, AND J. \\ BRISSWALTER ${ }^{1}$
}

\author{
${ }^{1}$ University of Toulon-Var \\ ${ }^{2}$ INSEP, Paris
}

\section{Summary}

After the swim to cycle transition of a triathlon, perceived exertion (RPE) during cycling was higher than during a single cycling bout for 8 well-trained triathletes, but swimming in a drafting position led to lower RPE responses and energy cost of cycling than swimming alone.

Numerous physiological and psychological factors have been suggested to account for successful performance during endurance events. Among psychological parameters, the perception of workload represents a major determinant of performance (Russell, 1997), as a positive or negative evaluation of the exercise's constraints could lead to either the continuation or the cessation of the competitive task. The technique most commonly used for the measurement of perceived exertion is the Rating Scale of Perceived Exertion (RPE, from 6 to 20) described by Borg (1970). This parameter is classically suggested to be a good indicator of physical stress and provides a complementary tool for training prescription, especially during long duration exercises where fatigue is likely to occur (Williams \& Eston, 1989).

In this context, most studies have been conducted during continuous unimodal events. During the last decade several multimodal events involving successive locomotion mode sessions such as triathlon have attracted increased attention of scientists. Further, introduction of drafting, i.e., swimming or cycling directly behind a competitor, has considerably modified the race strategy, as triathletes attempt to swim or cycle as fast as possible to stay in the leading group. During these events it has been shown that the succession of different exercises or different drafting strategies leads to specific physiological adaptation when compared with a unimodal sport (Hausswirth, Vallier, Lehenaff, Brisswalter, Smith, Millet \& Dreano, 2001). However, to our knowledge, relatively little information is available on the effect of successive exercises on the RPE scores. Therefore, the aim of the present study was to investigate whether RPE responses measured during a cycling session are affected by a prior swimming bout realized at a competition pace.

Eight well-trained triathletes competing at national level were tested during four experimental sessions. The first test was always a 750-m swim realized alone Ad at a competition pace (A: Swimming Alone). It was used to judge swimming intensity for each subject. During the three other tests, presented in counterbalanced order, subjects undertook a 15 -min. ride on a bicycle ergometer at $75 \%$ of maximal aerobic power (MAP) and at a freely chosen cadence (FCC). This test was preceded by either a 750-m swim performed alone at the pace adopted during Swimming Alone (SAC trial), a 750-rn swim in drafting position at the pace adopted during Swimming Alone (SDC trial), or a cycling warm-up (same duration as the swimming tests) at a power representing $30 \%$ of maximal aerobic power (MAP, C trial).

The subjects were asked to rate their perceived exertion (RPE 6-20 scale, Borg, 1970) immediately after the cessation of the swimming and cycling bouts. Moreover, blood lactate concentration was assessed immediately after swimming, and after 3 and 15 min. of cycling, and oxygen uptake (V02) was collected continuously during cycling. The RPE responses and physiological parameters measured during the cycling trials are presented in Table 1. Analysis showed that prior swimming alone led to significantly higher V02, Lactate, and RPE values during subsequent cycling when compared with cycling alone $(p<, 051$. Further, swimming in drafting position yielded significantly lower blood lactate concentration and RPE values measured during subsequent cycling in comparison with swimming alone $(\mathrm{p}<.05)$.

The main result was that RPE during cycling at a constant power output is significantly higher after a swimming bout. The similar evolution of RPE and physiological parameters confirms the hypothesis that RPE is a good indicator of exercise metabolic load (Williams \& Eston, 1989) even during multimodal events and could therefore be a useful tool during triathletes' training, especially to prescribe exercise intensity during combined swimming and cycling exercises. Moreover, the lower RPE responses obtained during the cycling session when preceded by a swimming bout performed in drafting position in comparison with an isolated swimming bout indicated that drafting strategies during competition lead, on the one hand, to a significant improvement in energy cost of locomotion, i.e., lower V02 and lactate values, and, on the other hand, to a lower perceived workload. Therefore, we suggest that drafting during swimming improved both physiological and psychological factors of triathlon performance. Further studies are still needed to validate this hypothesis during a triathlon competition. 


\section{REFERENCES}

BORG, G. A. V. (1970) Perceived exertion as an indicator of somatic stress. Scandinavian Journal of Rehabilitation Medicine, 2, $92-98$.

HAUSSWIRTH, C., VALliER J.-M., LEHENAFF D., BRISSWALTER, J., SMITH, D., . MILLET, G. ., \& DREANO, P. (2001) Effect of two drafting modalities in cycling on running performance. Medicine Science for Sports and Exercise, 33, 1-8.

RUSSELL,.W. D. (1997) On the current status of rated perceived exertion. Perceptual and Motor Skills, 84, 799-808.

WILLIAMS, J.G. , \& ESTON, R. G. (1989) Determination of the intensity in vigorous exercise programs with particular reference to the use of ratings of perceived exertion. Sports Medicine, 8, 177-189.

TABLE 1

PHYSIOLOGICAL PARAMETERS AND RATINGS OF PERCEIVED EXERTION MEASURED DURING SUBSEQUENT CYCLING (OXYGEN UPTAKE: V02, BLOOD LACTATE CONCENTRATION: LA) AFTER SWIMMING EXERCISE

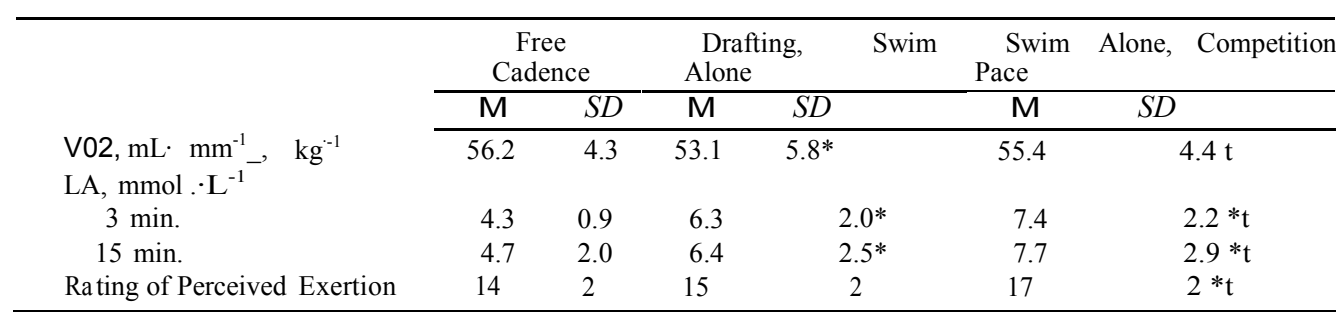

*Significantly different from Free Cadence trial $(p<.05)$. t Significantly different from Drafting, Swim Alone trial $(\mathrm{p}<.05)$. 